\title{
Tracking the Source of Metals to the San Juan River
}

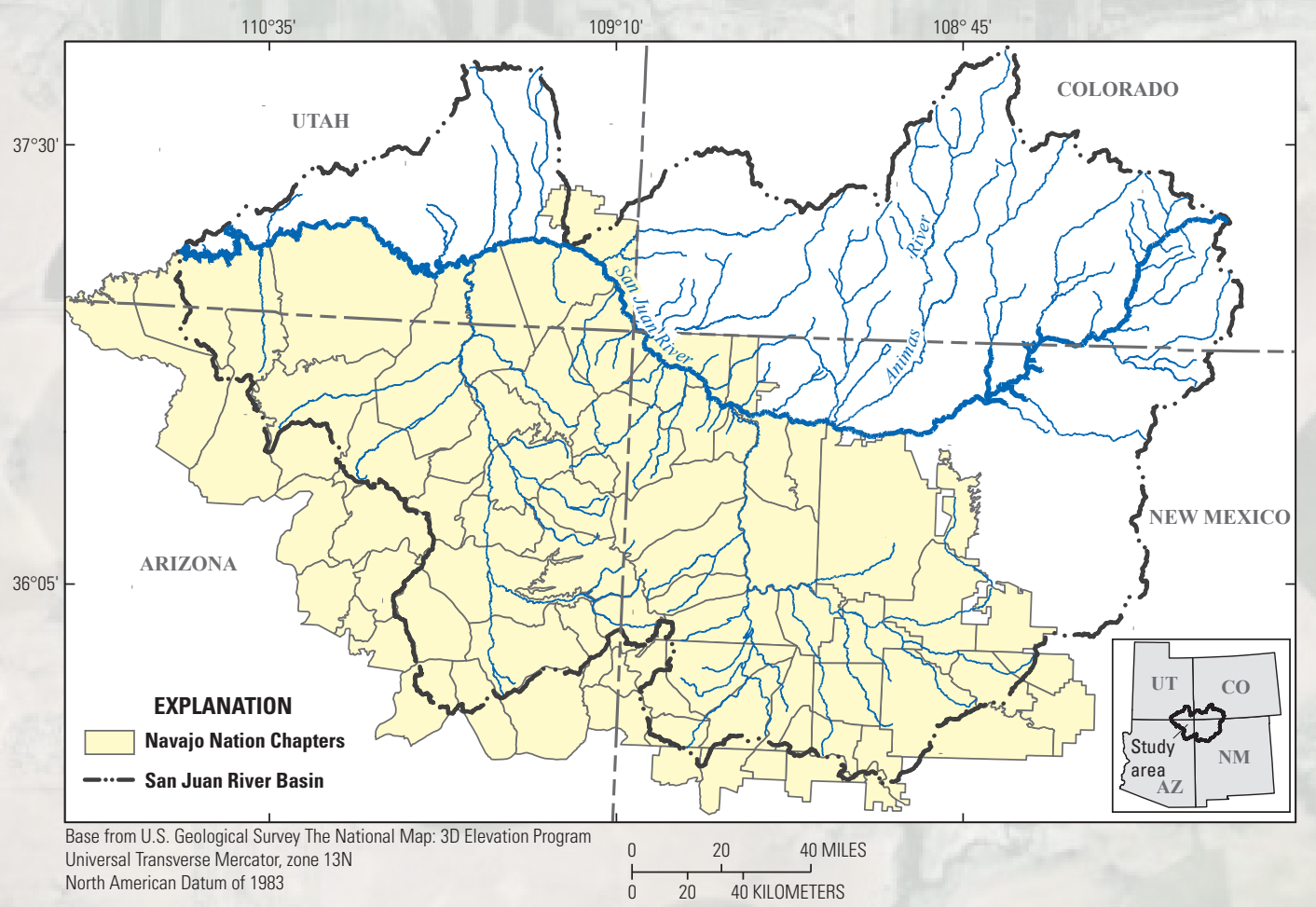

General study area showing the San Juan River Basin, San Juan River and tributaries, and boundaries of the Navajo Nation Chapters in and around the study area.

\section{Jutroduction}

The San Juan River is a major water source for communities in the Four Corners Region of the United States (Colorado, Arizona, New Mexico, Utah) and is a vital source of water for the Navajo Nation. The Navajo Nation Environmental Protection Agency (NNEPA) periodically samples surface water on the Navajo Nation and has found that some elements exceed NNEPA surface water standards (the upper limits of an element for consumption or other use of water). Constituents of concern are substances that could be harmful if present in sufficient quantities, and it is important to keep track of the concentrations of these substances in the environment. In the San Juan River, constituents of concern include metals detected in river water, such as arsenic, lead, and aluminum. These metals can come from natural sources or can result from human activities (anthropogenic) and can affect the health of people, plants, and animals. The Animas River is one natural source of metals to the San Juan River because of the types of rock through which the Animas River flows and because of hard rock mining at the headwaters. Other potential sources of metals are oil and gas development, coal mining, coal-fired power plants, urban areas, illegal trash dumping, abandoned uranium mines and mills, overgrazed areas, natural geology, and leaching from subsurface agricultural return flows. Determining how much each of these sources contributes and the relative effect of each source on San Juan River water will help the Navajo Nation in their efforts to protect human health and the environment along the San Juan River.

The U.S. Geological Survey (USGS) is working with the NNEPA to identify sources of metals and trace elements entering the San Juan River from tributaries in the reach flowing through the Navajo Nation and to quantify the contribution from each natural and human-caused source. The USGS and NNEPA worked with local community members to locate tributaries where sampling equipment was installed. The 3 -year sourcetracking project, starting in spring 2021, will identify where metals at concentrations above safe surface water standards might be entering the river by evaluating the chemical signatures of water in the major tributaries of the San Juan River. Results will provide valuable information to the Navajo Nation, public drinking-water managers, irrigation districts, other stakeholders, scientists, and the public.
Navajo Nation Chapters In and Around the San Juan River Basin

\begin{tabular}{ll}
\hline & Chapter \\
\hline Aneth & Nazlini \\
Becenti & Nenahnezad \\
Beclabito & Newcomb \\
Black Mesa & Ojo Encino \\
Burnham & Oljato \\
Casamero Lake & Pinedale \\
Chilchinbeto & Pinon \\
Chinle & Pueblo Pintado \\
Church Rock & Red Lake \#18 \\
Counselor & Red Mesa \\
Cove & Red Valley \\
Coyote Canyon & Rock Point \\
Crownpoint & Rock Springs \\
Crystal & Rough Rock \\
Dennehotso & Round Rock
\end{tabular}

Forest Lake Sanostee

Fort Defiance Sawmill

Ganado

Hogback

Sheep Springs

Shiprock

Huerfano

Shonto

Inscription House

Kayenta

Standing Rock

Kinlichee

Steamboat

Lake Valley

Sweetwater

Littlewater

Tachee/Blue Gap

Low Mountain

Teec Nos Pos

Tohatchi

Lukachukai

Torreon/Star Lake

Many Farms

Tselani/Cottonwood

Mariano Lake

Twin Lakes

Mexican Springs

Upper Fruitland

Mexican Water

Wheatfields/Tsaile/ Blackrock

Nageezi

Whippoorwill Springs

Nahodishgish

White Horse Lake

Naschitti

White Rock

Navajo Mountain 
[EPA, U.S. Environmental Protection Agency; MCL, maximum contaminant level; NNEPA, Navajo Nation Environmental Protection Agency; $\mu \mathrm{g} / \mathrm{L}$, micrograms per liter; Concentrations are total (unfiltered) unless otherwise indicated; *, dissolved (filtered); NCNS, no current numerical standard; mg/L, milligrams per liter]

\begin{tabular}{|c|c|c|c|c|c|c|c|c|c|c|}
\hline \multirow[b]{2}{*}{ Element } & \multirow[b]{2}{*}{ EPA MCL' } & \multicolumn{8}{|c|}{ Navajo Nation Surface Water Quality Standards by designated use (NNEPA, written commun., 2015) } & \multirow[b]{2}{*}{ Potential human effects } \\
\hline & & $\begin{array}{l}\text { Domestic } \\
\text { water } \\
\text { supply }\end{array}$ & $\begin{array}{l}\text { Fish con- } \\
\text { sumption }\end{array}$ & $\begin{array}{l}\text { Primary } \\
\text { human } \\
\text { contact }\end{array}$ & $\begin{array}{l}\text { Second- } \\
\text { ary human } \\
\text { contact }\end{array}$ & $\begin{array}{l}\text { Aquatic } \\
\text { and wild- } \\
\text { life acute }\end{array}$ & $\begin{array}{l}\text { Aquatic } \\
\text { and } \\
\text { wildlife } \\
\text { chronic }\end{array}$ & $\begin{array}{l}\text { Agricul- } \\
\text { tural water } \\
\text { supply }\end{array}$ & $\begin{array}{l}\text { Livestock } \\
\text { watering }\end{array}$ & \\
\hline $\begin{array}{l}\text { Arsenic } \\
\text { (As) }\end{array}$ & $10 \mu \mathrm{g} / \mathrm{L}$ & $10 \mu \mathrm{g} / \mathrm{L}$ & & & & $340 \mu \mathrm{g} / \mathrm{L}^{*}$ & $150 \mu \mathrm{g} / \mathrm{L}^{*}$ & $2,000 \mu \mathrm{g} / \mathrm{L}$ & $200 \mu \mathrm{g} / \mathrm{L}$ & $\begin{array}{l}\text { Long-term exposure } \\
\text { above the MCL can } \\
\text { cause skin damage } \\
\text { and problems with } \\
\text { circulatory systems } \\
\text { and may cause } \\
\text { increased risk of } \\
\text { getting cancer } \\
\text { (EPA, 2021a). }\end{array}$ \\
\hline Lead $(\mathrm{Pb})$ & $15 \mu \mathrm{g} / \mathrm{L}^{2}$ & $15 \mu \mathrm{g} / \mathrm{L}$ & NCNS & $15 \mu \mathrm{g} / \mathrm{L}$ & $15 \mu \mathrm{g} / \mathrm{L}$ & $\begin{array}{l}\text { Depends } \\
\text { on the } \\
\text { hard- } \\
\text { ness }\end{array}$ & $\begin{array}{l}\text { Depends } \\
\text { on the } \\
\text { hard- } \\
\text { ness }\end{array}$ & $\begin{array}{r}10,000 \\
\mu \mathrm{g} / \mathrm{L}\end{array}$ & $100 \mu \mathrm{g} / \mathrm{L}$ & $\begin{array}{l}\text { Long-term exposure } \\
\text { to lead can cause } \\
\text { infants and children } \\
\text { to have delayed } \\
\text { physical or mental } \\
\text { development. } \\
\text { Adults can develop } \\
\text { kidney problems or } \\
\text { high blood pressure } \\
\text { (EPA, 2021b). }\end{array}$ \\
\hline $\begin{array}{l}\text { Aluminum } \\
\text { (Al) }\end{array}$ & $\begin{array}{c}0.05-0.2 \\
\mathrm{mg} / \mathrm{L}^{3}\end{array}$ & NCNS & NCNS & NCNS & NCNS & $750 \mu \mathrm{g} / \mathrm{L}^{4}$ & $87 \mu \mathrm{g} / \mathrm{L}^{4}$ & $\begin{array}{r}20,000 \\
\mu \mathrm{g} / \mathrm{L}\end{array}$ & NCNS & $\begin{array}{l}\text { High Al will dis- } \\
\text { color water (EPA, } \\
2021 \text { b). }\end{array}$ \\
\hline
\end{tabular}

${ }^{1}$ The MCL is the highest level of a contaminant that is allowed in drinking water. Below this level, there is no known or expected risk to health (EPA, 2021a).

${ }^{2}$ Drinking-water MCL action level is the concentration of lead in the water that alerts the user to check the corrosiveness of water. Lead is released from pipes or from erosion of natural deposits (EPA, 2021a).

${ }^{3}$ The secondary drinking-water MCL is a value to aim for that will not affect color, taste, or smell of the water. These elements are not a health threat.

${ }^{4}$ Acid-soluble aluminum: The aluminum that passes through a 0.45 -micrometer filter after the sample has been acidified to a pH between 1.5 and 2.0 with nitric acid.

\section{Units of measure for metals in water or sediment}

1 milligram per liter (mg/L) or

milligram per kilogram $(\mathrm{mg} / \mathrm{kg})=1$ part per million $(\mathrm{ppm})$

or 1 minute over 2 years or 4 drops in a 55 gallon drum.
1 microgram per liter $(\mu \mathrm{g} / \mathrm{L})$ or

microgram per kilogram $(\mu \mathrm{g} / \mathrm{kg})=1$ part per billion $(\mathrm{ppb})$

or 1 second in nearly 32 years or 1 drop in a tanker truck.
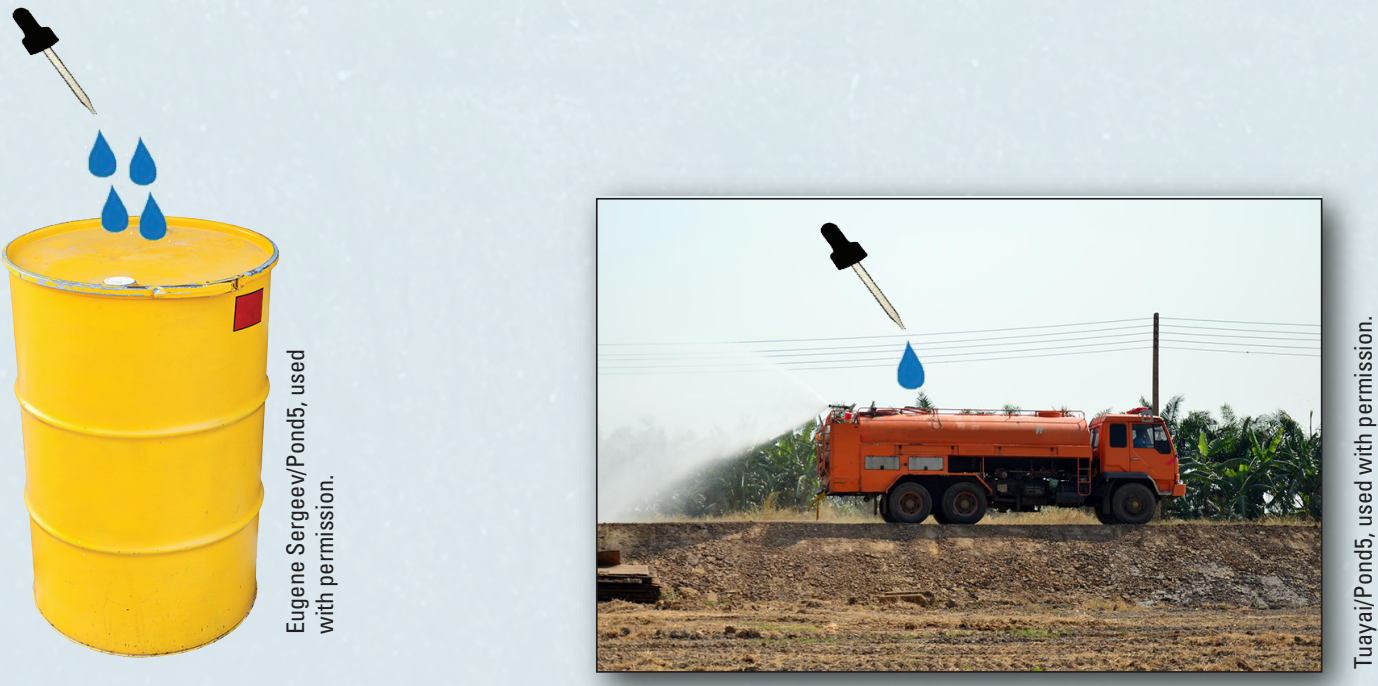


\section{Conceptual Model of Potential Sources of Metals to the San Juan River}

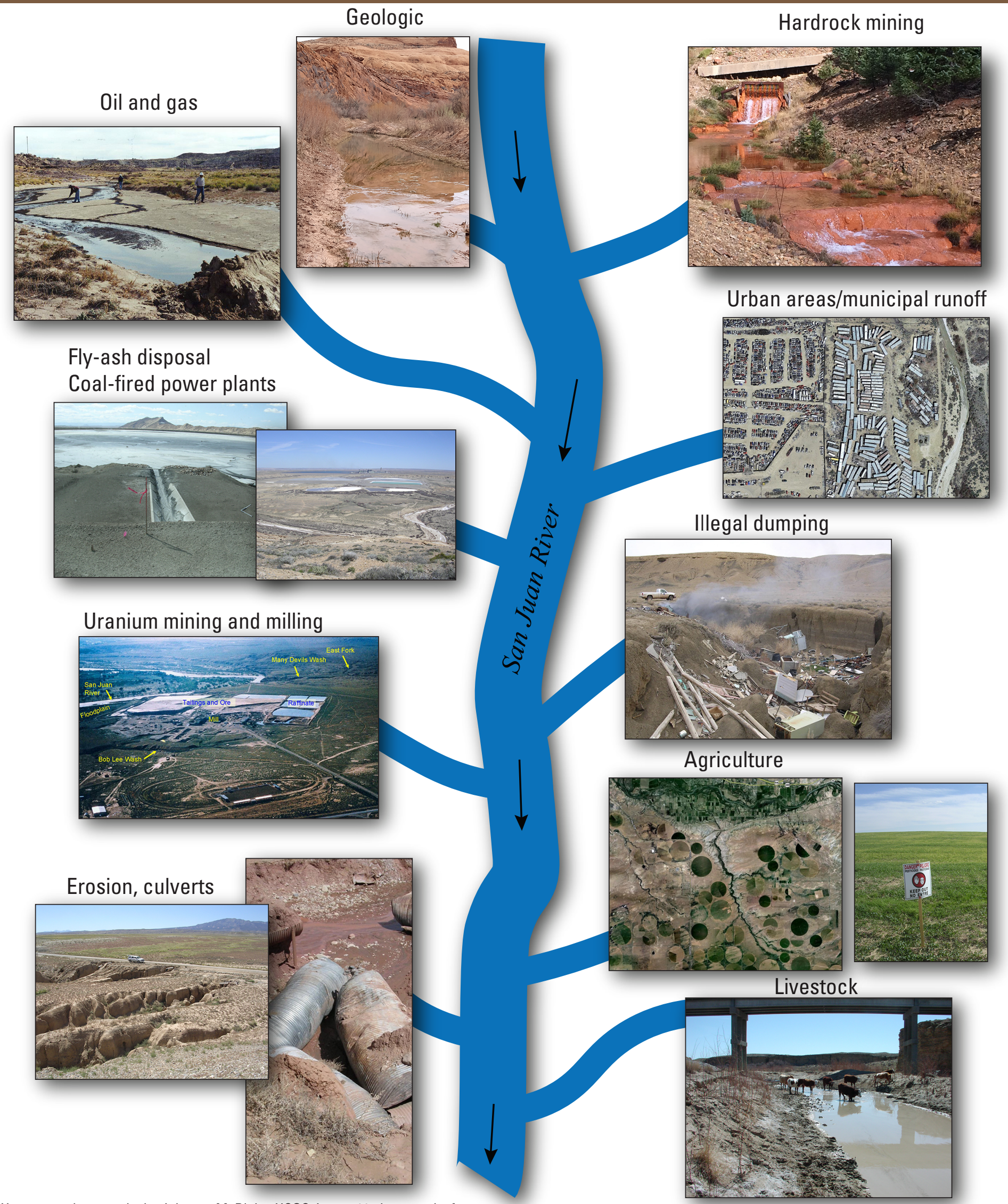




\section{Approath andil Tools}

- Compile published background information on the chemistry of rocks, sediments, and water to identify the potential sources of metals and trace elements to the San Juan River and to identify information gaps. Comparing the chemistry of potential inputs will help differentiate contributions to the San Juan River from different sources.

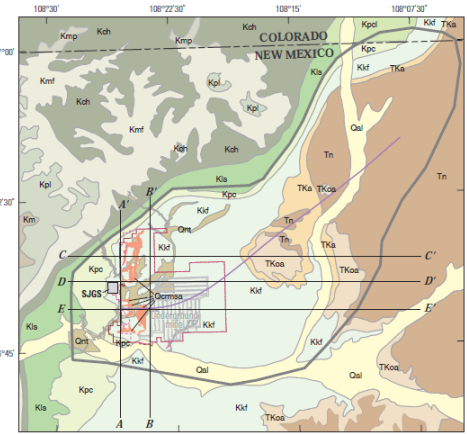

Information from geologic maps helps to establish natural sources of specific constituents.
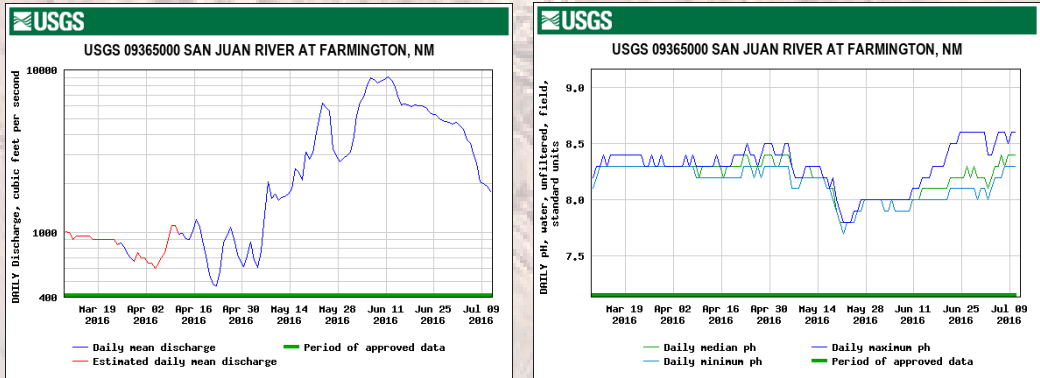

Historical streamflow and water quality data provide information on changes in hydrology over time. Streamflow and water quality values can change naturally over time with the seasons or as a result of human activities.

- Collect and analyze surface water samples and suspended sediment in the San Juan River and its tributaries to determine where elements are coming from and where they end up in the river.

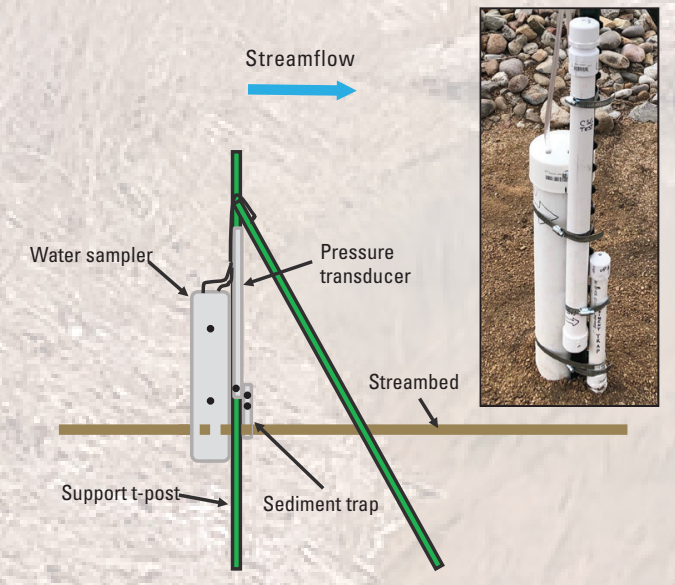

Sediment chemistry gages collect water and suspended sediment and consist of a water sampler, suspended sediment trap, and pressure transducer. The pressure transducer contains a sensor that measures the water level when water is in a stream channel.

- Quantify streamflow where it is unknown. Measuring tributary streamflow will help to determine the relative contribution of each source to the San Juan River.

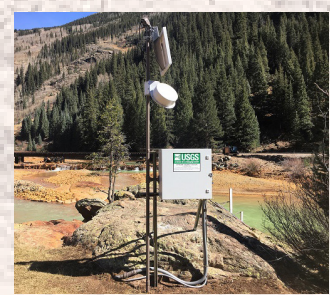

(Above) A USGS streamgage along a river channel can deliver near-realtime streamflow information and water quality data in some cases.

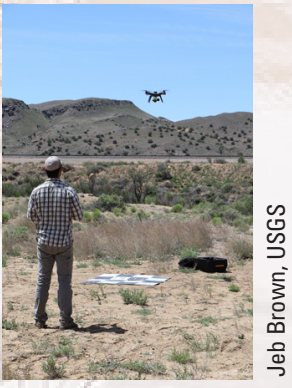

(Above right) In places where the installation of a USGS streamgage is not possible, unmanned aircraft systems (UAS) can be used to collect data for calculation of stream channel dimensions. The channel dimensions are then used with water levels from the sediment chemistry gage to calculate streamflow in channels that are not equipped with streamgages. Streamflow data and metal concentrations (amount per volume of water) can be used together to calculate the metal load (concentration multiplied by stream discharge) in the tributaries of the San Juan River.
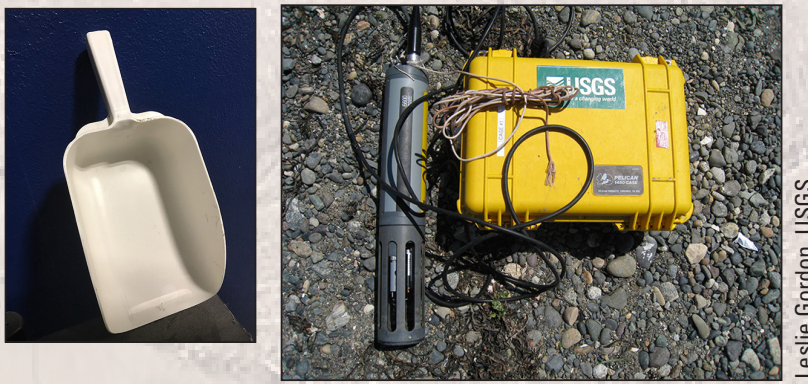

The bed material sampler (left) is used to collect sediment in the channel bottom, and the water quality probe (right) is used to collect water quality information such as $\mathrm{pH}$.

\section{References Cited}

U.S. Environmental Protection Agency [EPA], 2021a, National primary drinking water regulations: U.S. Environmental Protection Agency web page, accessed April 15, 2021, at https://www.epa.gov/ ground-water-and-drinking-water/national-primary-drinking-waterregulations\#Inorganic.

U.S. Environmental Protection Agency [EPA], 2021b, Secondary drinking water standards - Guidance for nuisance chemicals: U.S. Environmental Protection Agency web page, accessed April 15, 2021, at https://www.epa.gov/sdwa/secondary-drinking-water-standardsguidance-nuisance-chemicals.

By Johanna M. Blake, Shaleene B. Chavarria, and Anne-Marie Matherne

For additional information, contact:

Director, USGS New Mexico Water Science Center

6700 Edith Blvd. NE, Albuquerque, NM 87113

Email:dc_nm@usgs.gov

Telephone: 505-830-7900

For more information about this project and the work done by the USGS and NNEPA, please go to

https://www.usgs.gov/centers/nm-water/science/investigationssources-contaminants-concern-san-juan-river

https://www.usgs.gov/centers/nm-water/science

https://www.navajoepa.org 